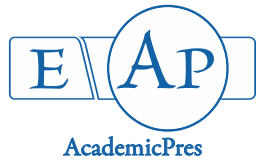

\title{
Genetic Diversity Based on ISSR Markers of Apple Genotypes in Ardahan, Turkey
}

\author{
Emre SEVİNDİK ${ }^{1 *}$, Hüseyin UYSAL ${ }^{1}$, Zehra Tuğba MURATHAN ${ }^{2}$ \\ ${ }^{1}$ Adnan Menderes University, Faculty of Agriculture, Department of Agricultural Biotechnology, South Campus, Cakmar, Aydin, \\ Turkey;ph.d-emre@hotmail.com (*correspondingauthor); huysal07@yahoo.com \\ ${ }^{2}$ Ardahan University, Faculty of Engineering, Department of Food Engineering, Ardahan, Turkey; ztugbaabaci@hotmail.com
}

\begin{abstract}
Within the present study, it was conducted a genetic diversity analysis using ISSR markers for some apple genotypes grown in Ardahan region, Turkey. Total genomic DNA (gDNA) isolation from apple leaves was performed using commercial kits. Five ISSR primers were used to determine the genetic diversity among the genotypes studied. Polymerase Chain Reaction (PCR) was performed with all gDNA samples to produce bands to score. PCR products were run in agarose gel and visualized under UV light. Bands on the gels were scored as "1", while no bands at the corresponding positions were scored as "0", to generate the matrix file. Five ISSR primers produced a total of 35 bands, and 21 of them were polymorphic. The polymorphic bands rated approximately $60 \%$. Phylogenetic relationships and genetic distances between the genotypes were calculated by using the PAUP [Phylogenetic Analysis Using Parsimony (and Other Methods)] program. According to the PAUP data, the closest genetic distance was 0.03704 between 'Kaburga' and 'Japon Apple' genotypes, while the furthest genetic distance was 0.48148 between 'Karanfil Apple' and 'Sisli Uruset'. The phylogenetic analysis obtained using UPGMA algorithm produced a phylogenetic tree with two clades. The results suggest that ISSR markers are useful tools for determining genetic relationships among apple genotypes.
\end{abstract}

Keywords: apple; Ardahan; genetic diversity; ISSR

\section{Introduction}

Rosaceae is one of the most diversified and large plant families, including economically important fruit trees. This family consists of more than 100 genera and 3,000 species and it is the third most important plant family in terms of economic significance in mild climate regions (Zarei $e t$ al., 2017). The family, which generally includes taxa in tree and bush forms, also comprises herbaceous taxa. The family members, which have cosmopolite characteristics, are mostly spread in the Northern hemisphere (Serdar et al., 2014).

Apple (Malus domestica) of the Rosaceae family is one of the most important cultivated fruit trees in the mild climate regions of the world (Mahmood et al., 2016). Apple has been reported to be distributed to different gene centers in the world, primarily Europe, Anatolia, Himalaya, China,
Japan, Korea and North America with its 48 species (Dziubiak, 2004; Ercişli, 2004). Turkey is one of the most important producers of apples, with an estimated production of 2,925,828 tons in 2016 (Fao, 2016). There are over 460 local apple genotypes in Turkey, all with different qualities (Ertürk and Akçay, 2010). Apple is one of the most important fruit species, commonly preferred by consumers due to its taste, nutritional content and economic value; its nutritive components include dietary fiber, as well as rich antioxidant active ingredients, carbohydrates and essential minerals (Wiseman, 2001; Sadik et al., 2003). It is a good source of phenolics and antioxidants for humans (Wolfe et al., 2003; Wolfe and Liu, 2003; Abaci and Sevindik, 2014).

Molecular marker methods are based on the principle of determining polymorphic regions in DNA molecules. Molecular markers are commonly used with the purpose of detecting genetic polymorphism, genetic identification, hybrid plant identification for hybridization development, genetic mapping and marker-assisted selection (Jiang, 2013; Sesli and Yegenoglu, 2017). One of the techniques is ISSR (Inter Simple Sequence Repeat) which offers excellent means to investigate genetic diversity of plants (Arslan and 
Tamkoç, 2011; Abou-Deif et al., 2013). In the present day, the ISSR technique is frequently used for determining the genetic diversity of apple genotypes (Goulao and Oliveira, 2001; Korbin et al., 2002; He et al., 2011; Uzun et al., 2016). Development of the ISSR technique has ensured the rapid use of the organisms in the studies of genetic variability. The ISSR is based on the PRC amplification of DNA fragments between two reversed, simple sequential recurrence regions of expandable distances (Zietkiewicz et al., 1994).

In the present study, it was investigated the genetic diversity using ISSR markers for some apple genotypes grown in the Ardahan region of Turkey.

\section{Materials and Methods}

\section{Plant samples and genomic DNA isolation}

Leaf samples of apple genotypes used in the study were collected from certain regions in Ardahan (Turkey) between July and August, 2015 (Fig. 1). Total genomic DNA (gDNA) samples were extracted using DNeasy Plant Mini Kit (GeneMark). The gDNA samples were stored at $20^{\circ} \mathrm{C}$ when not at use.

\section{PCR amplification}

In order to visualize gDNA samples, $0.8 \%$ standard agarose gel electrophoresis procedure was performed. For ISSR-PCR amplification, five ISSR primers were used (Table 1). ISSR amplification reactions were carried out in $25 \mu \mathrm{L}$ volume containing $5 \mu \mathrm{L}$ master mix (PCR buffer, $\mathrm{MgCl}_{2}$, dNTP, Taq DNA polymerase), $1 \mu \mathrm{L}$ ISSR primers, $2.0 \mu \mathrm{L} \mathrm{gDNA}$ (around $10 \mathrm{ng} / \mu \mathrm{L}$ ) and $17 \mu \mathrm{L}$ of $d_{d} \mathrm{H}_{2} \mathrm{O}$.

Table 2 shows the ISSR-PCR cycles with their respective conditions. Amplification products were analyzed by electrophoresis on $0.8 \%$ agarose gels buffered with $0.5 \mathrm{X}$ TBE (Tris-Borate-EDTA), stained with ethidium bromide and pictured under ultraviolet light (Figs. 2 and 3 ).

\section{Data analysis}

The pictures were used for the evaluation of the results in the analysis of ISSR-PCR. In the reading of the bands formed at the end of the amplification, only the bright bands were taken into consideration.

The presence (1) and absence (0) of bands were specified to construct the data matrix. PAUP [Phylogenetic Analysis Using Parsimony (and Other Methods)] Version 4.0b10 (Swofford, 2002) was used to perform phylogenetic analyses using ISSR data.

Table 1. Primers used in the ISSR-PCR reactions and their Tm degrees

\begin{tabular}{ccc}
\hline Primer & DNA Sequences \\
\hline UBC-831 & 5'-CTCTCTCTCTCTCTCTT-3' \\
UBC-830 & 5'-TGTGTGTGTGTGTGTGG-3' \\
UBC-807 & 5'-AGAGAGAGAGAGAGAGT-3' & 50 \\
UBC-826 & 5'ACACACACACACACACC-3' & 50 \\
UBC-808 & 5'-AGAGAGAGAGAGAGAGC-3' & 52 \\
\hline
\end{tabular}

Table 2. Cycles and conditions of ISSR-PCR reactions

\begin{tabular}{|c|c|c|c|}
\hline Pre-heating & $94^{\circ} \mathrm{C}$ & $4 \mathrm{~min}$ & 1 cycle \\
\hline 1. step & $94^{\circ} \mathrm{C}$ & $1 \mathrm{~min}$ & \\
\hline 2. step & $50-52^{\circ} \mathrm{C}$ & $1 \mathrm{~min}$ & \\
\hline 3. step & $72^{\circ} \mathrm{C}$ & $1 \mathrm{~min}$ & 35 cycles \\
\hline 4. step & $72{ }^{\circ} \mathrm{C}$ & $10 \mathrm{~min}$ & 1 cycle \\
\hline 5. step & $4^{\circ} \mathrm{C}$ & $20 \mathrm{~min}$ & \\
\hline
\end{tabular}

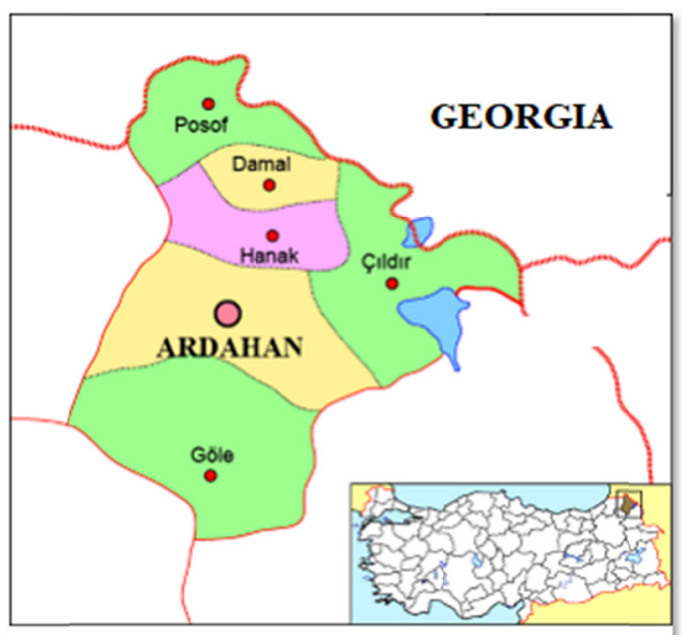

Fig. 1. Location of Ardahan Province, Turkey 
556

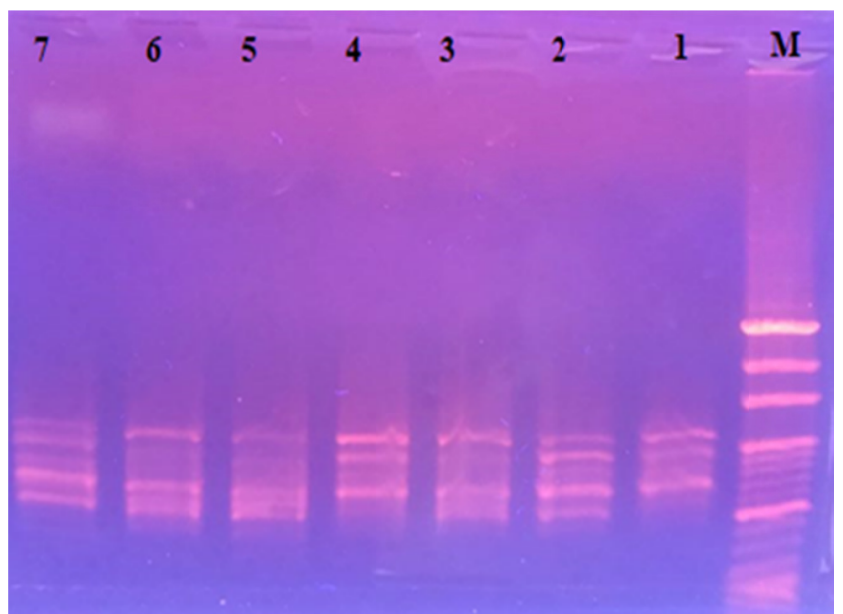

Fig. 2. ISSR-PCR gel photo amplified with UBC-826

\section{Results and Discussion}

In the ISSR-PCR analysis, a total of 35 bands were detected, among which 21 bands were polymorphic and the polymorphism rate was $60 \%$. PAUP $4.0 \mathrm{~b} 10$ analysis program was used to calculate the phylogenetic trees and genetic distances between populations. According to the PAUP data, the closest genetic distance was 0.03704 between 'Kaburga Apple' and 'Japon' genotypes, while the furthest genetic distance was 0.48148 between 'Karanfil Apple' and 'Sisli Uruset' (Table 3).

The phylogenetic tree was obtained using the UPGMA algorithm, and the tree was consisted of two clades (Fig. 4). Clade 1 was divided into five groups. Group A consisted of 'Sobe Apple', 'Kırmızı Safran', 'Kaba Apple' and 'Limon Apple', group B consists of 'Sarı Safran' and 'Yaz Apple', group C consist of 'Kaburga Apple' and' Japon Apple', group D consist of 'Uruset Apple; 'Şah Apple' and 'Sisli Uruset' and group E consist of 'Paşa Apple' and 'Karpuz Apple'. Clade 2 consisted of only 'Karanfil Apple' (Fig. 4).

Uzun et al. (2016) used ISSR markers to detect Turkish apple genotypes and their relationships with some foreign

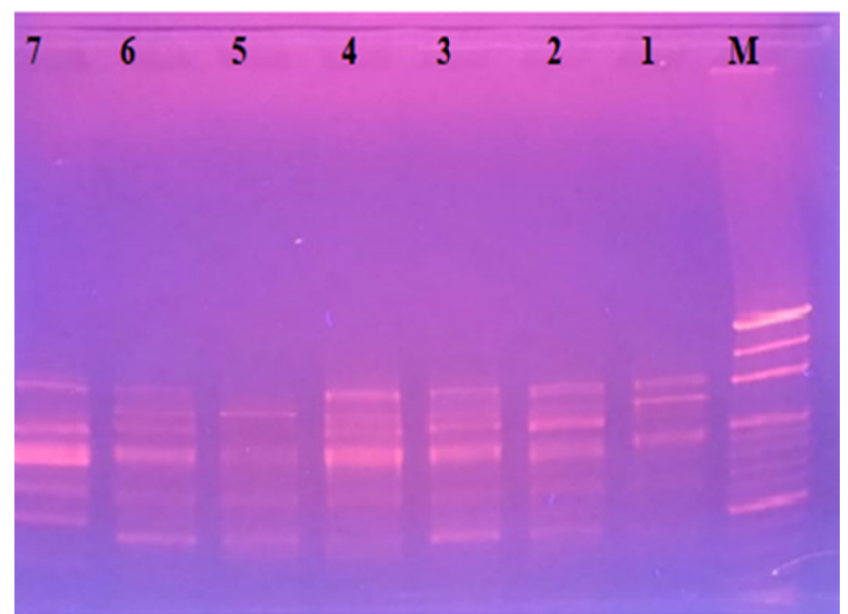

Fig. 3. ISSR-PCR gel photo amplified with UBC-830

genera and species. In their study, apple genotypes named 'Yaz', 'Karanfil', 'Paşa' and 'Şalh' were found in the same group, while 'Kaba' apple was found in a different group. In the present study, the apple genotypes named 'Paşa', 'Yaz', 'Sah' and 'Kaba' were detected in Clade 1, while 'Karanfil Ảpple' was found in Clade 2. Osmanoğlu (2008) revealed genetic relationships of apple genotypes collected from Ardahan/Posof region using RAPD markers. In their study, apple genotypes named 'Kırmızı Safran', 'Sarı Safran', 'Kaburga' and 'Sobe' were found in the same group. These four genotypes took place in Clade 1 according to the UPGMA dendrogram obtained via ISSR data in the present study (Fig. 4). Osmanoğlu (2008) detected 'Paşa' and 'Uruset' apples in a group, while found 'Yaz' and 'Kaba' apples in another group. In the present study, on the other hand, 'Paşa' and 'Kaba', 'Uruset' and 'Yaz' apples were detected in Clade 1 . The results were found partially similar. Daler et al. (2017) have studied the genetic relationships among six apple varieties cultivated in our country using RAPD markers. 10 RAPD primers produced 47 polymorphic bands. Kaya et al. (2015) carried out molecular analysis of apple genotypes collected from Van province, through using RAPD markers.

Table 3. Pairwise sequence distances among some apple genotypes for ISSR data using PAUP 4.0b10 distance matrix

\begin{tabular}{|c|c|c|c|c|c|c|c|c|c|c|c|c|c|c|}
\hline Genotypes & 1 & 2 & 3 & 4 & 5 & 6 & 7 & 8 & 9 & 10 & 111 & 12 & 13 & 14 \\
\hline $\begin{array}{l}\text { 'Sobe } \\
\text { Apple' }\end{array}$ & - & 0.07407 & 0.13636 & 0.18519 & 0.29630 & 0.185 .19 & 0.25926 & 0.22222 & 0.33333 & 0.37037 & 0.371037 & 0.25926 & 0.29630 & 0.25926 \\
\hline $\begin{array}{l}\text { 'Kurmizı } \\
\text { Safran' }\end{array}$ & 2 & - & 0.13636 & 0.18519 & 0.29630 & 0.11111 & 0.33333 & 0.14815 & 0.25926 & 0.37037 & 0.29630 & 0.33333 & 0.37037 & 0.18519 \\
\hline $\begin{array}{l}\text { 'Kaba } \\
\text { Apple' }\end{array}$ & 3 & 3 & - & 0.27273 & 0.40909 & 0.18182 & 0.31818 & 0.27273 & 0.40909 & 0.27273 & 0.36 .364 & 0.22727 & 0.36364 & 0.31818 \\
\hline $\begin{array}{l}\text { 'Sarı } \\
\text { Safran' }\end{array}$ & 5 & 5 & 6 & - & 0.11111 & 0.22222 & 0.29630 & 0.25926 & 0.29630 & 0.33333 & 0.25926 & 0.29630 & 0.33333 & 0.22222 \\
\hline 'Yaz Apple' & 8 & 8 & 9 & 3 & - & 0.28571 & 0.33333 & 0.29630 & 0.20000 & 0.28571 & 0.201000 & 0.25926 & 0.22857 & 0.28571 \\
\hline $\begin{array}{l}\text { 'Limon } \\
\text { Apple' }\end{array}$ & 5 & 3 & 4 & 6 & 10 & - & 0.37037 & 0.18519 & 0.31429 & 0.34286 & $0.25,714$ & 0.37037 & 0.34286 & 0.22857 \\
\hline $\begin{array}{l}\text { 'Karanfil } \\
\text { Apple' }\end{array}$ & 7 & 9 & 7 & 8 & 9 & 10 & - & 0.40741 & 0.44444 & 0.40741 & 0.48148 & 0.44444 & 0.33333 & 0.37037 \\
\hline $\begin{array}{l}\text { 'Kaburga } \\
\text { Apple' }\end{array}$ & 6 & 4 & 6 & 7 & 8 & 5 & 11 & - & 0.11111 & 0.22222 & 0.14815 & 0.25926 & 0.22222 & 0.03704 \\
\hline $\begin{array}{l}\text { 'Uruset } \\
\text { Apple' }\end{array}$ & 9 & 7 & 9 & 8 & 7 & 11 & 12 & 3 & - & 0.14286 & 0.11429 & 0.22222 & 0.14286 & 0.20000 \\
\hline 'Şah Apple' & 10 & 10 & 6 & 9 & 10 & 12 & 11 & 6 & 5 & - & 0.08571 & 0.11111 & 0.11429 & 0.22857 \\
\hline $\begin{array}{c}\text { 'Sisli } \\
\text { Uruset' }\end{array}$ & 10 & 8 & 6 & 7 & 7 & 9 & 13 & 4 & 4 & 3 & - & 0.18519 & 0.14286 & 0.14286 \\
\hline $\begin{array}{l}\text { 'Paşa } \\
\text { Apple' }\end{array}$ & 7 & 9 & 5 & 8 & 7 & 10 & 12 & 7 & 6 & 3 & 5 & - & 0.11111 & 0.29630 \\
\hline $\begin{array}{l}\text { 'Karpuz } \\
\text { Apple' }\end{array}$ & 8 & 10 & 8 & 9 & 8 & 12 & 9 & 6 & 5 & 4 & 5 & 3 & - & 0.22857 \\
\hline $\begin{array}{l}\text { 'Japon } \\
\text { Apple' }\end{array}$ & 7 & 5 & 7 & 6 & 10 & 8 & 10 & 1 & 7 & 8 & 5 & 8 & 8 & - \\
\hline
\end{tabular}




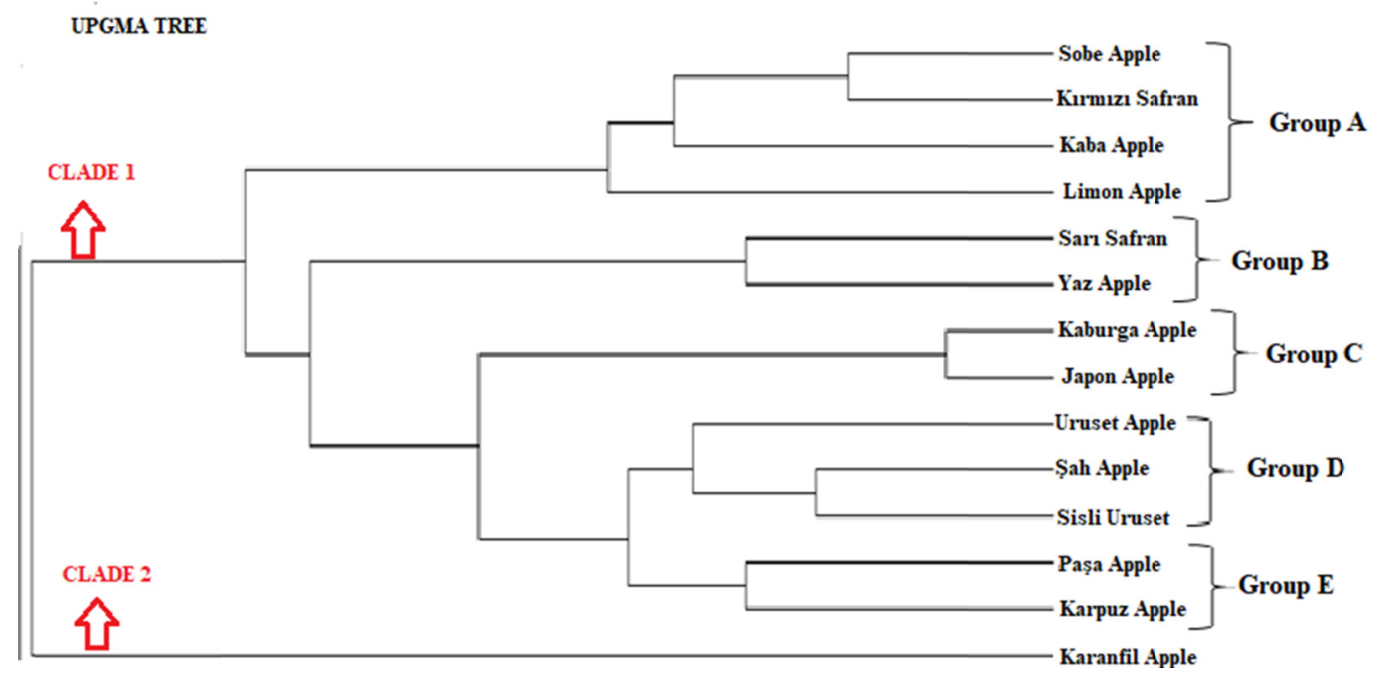

Fig. 4. The UPGMA tree generated using ISSR data of apple genotypes

Creating a dendrogram, the similarity index between genotypes was revealed. Molecular techniques including SSR (Hokanson et al., 1998; Kenis and Keulemans, 2005), AFLP (Kenis and Keulemans, 2005), nrDNA ITS, cpDNA matK (Robinson et al., 2001), cpDNA atpB-rbcL (Savolainen et al., 1995), promoter region of atp B gene (Mahmood et al., 2016), have been used to determine taxonomic status, genetic diversity and phylogenetic analyses among apple species and genotypes.

\section{Conclusions}

The study reports the genetic relationships between 14 apple genotypes distributed in Ardahan province by using five ISSR primers. Genetic distance and phylogenetic relationship among the target populations were detected based on ISSR data, and the relationships were visualized on the phylogenetic tree constructed. The obtained results will be useful to serve plant breeding programs by means of revealing inter-species genetic relationships which have a great importance in breeding studies. Furthermore, it was also aimed to offer information about the relationships between different populations cultivated in the region. Undoubtedly, more data including more taxa (e.g. morphological and/or DNA sequence data) will improve this conclusion and yield more reliable results.

\section{Acknowledgements}

The research was supported by the Aydin Adnan Menderes University [grant number (2015/ZRF15041)].

\section{References}

Abac ZT, Sevindik E (2014). Ardahan Bölgesinde Yetiştirilen Elma Çeşitlerinin Biyoaktif Bilesiklerinin ve Toplam Antioksidan Kapasitesinin Belirlenmesi. Yüzz̈ncü Yıl Üniversitesi Tarım Bilimleri [Determination of bioactive compounds and total antioxidant capacity of apple varieties grown in Ardahan region. Yüzz̈ncü Yil University Agricultural Sciences.Dergisi 24(2):175-184
Abou-DeifHM, Rashed AM, Sallam AAM, Mostafa HAE, Ramadan AW (2013). Characterization of twenty wheat varieties by ISSR markers. Middle-EastJournal ofScientific Research 15(2):168-175.

Arslan E, Tamkoç A (2011). The application of ISSR-PCR to determine the genetic relationship and genetic diversity between narrow leaved bluegrass (Poa angustifolia) and rough bluegrass( Poa trivialis) accessions. Turkish Journal ofBiology 35(4):415-423.

Daler S, Aşkin MA, Karakurt Y (2017). Bazı Birbirine Benzer Elma (Malus domestica L.) Genotiplerinde Pomolojik ve Moleküler Yöntemlerle Genetik Akrabalk Derecelerinin Tespiti [Determination of genetic relation levels by pomological and molecular methods in some genetically similar apple (Malus domestica L.) genotypes].Süleyman Demirel Üniversitesi Fen Bilimleri Enstitïsü Dergisi 21(2):444 452.

Dziubiak M (2004). Collection of the genus Malus Mill. in the botanical garden of the Polish Academy of Sciences in Warsaw. Journal of Fruit and Ornamental Plant Research 12:121-128.

Ercişli S (2004). A short review of the fruit germplasm resources of Turkey. Genetic Resourcesand Crop Evolution 51(4):419-435.

Ertürk U, Akçay ME (2010). Genetic variability in accessions of 'Amasya' apple cultivar using RAPD markers. Notulae Botanicae Horti Agrobotanici Cluj-Napoca38(3):239-245.

FAO(2016). Retrieved on 12 September 2018 from http://apps.fao.org

Goulao L, Oliveira CM (2001). Molecular characterisation of cultivars of apple (Malus $\times$ domestica Borkh.) using microsatellite (SSR and ISSR) markers. Euphytica 122(1):81-89.

He P, Li L, Li H, Wang H, YangJ, Wang Y (2011). Genetic analysis of wild apple resources in Shandong province based on inter-simple sequence repeats (ISSR) and sequence-specific amplification polymorphism (SSAP) markers. Afican Journal of Biotechnology 10(46):9501-9508.

Hokanson SC, Szewc-McFadden AK, Lamboy WF, McFerson JR (1998). Microsatellite (SSR) markers reveal genetic identities, genetic diversity and relationships in a Malus $\times$ domestica Borkh. core subset collection. Theoretical and Applied Genetics 97(5-6):671-683.

Jiang GL (2013). Molecular markers and marker-assisted breeding in plants. In Plant Breeding from Laboratories to Fields. InTech. 
558

Kaya T, Balta F, Şensoy S (2015). Fruit quality parameters and molecular analysis of apple germplasm resources from Van Lake Basin, Turkey. Turkish Journal of Agriculture and Forestry39(6):864875.

Kenis K, Keulemans J (2005). Genetic linkage maps of two apple cultivars (Malus $\times$ domestica Borkh.) based on AFLP and microsatellite markers. Molecular Breeding 15(2):205-219.

Korbin M, Kuras A, Zurawicz E (2002). Fruit plant germplasm characterisation using molecular markers generated in RAPD and ISSRPCR Cellular and Molecular Biology Letters 7(2B):785-794.

Mahmood T, Bakht NU, Aziz E (2016). Computational analysis of atpB gene promoter from different Pakistani apple varieties. Computational Biology and Chemistry 64:1-8.

Osmanoglu A (2008). Posof(Ardahan) Yöresi Elma Genetik Kaynaklarının Fenolojik, Morfolojik, Pomolojik Ve Moleküler Tanımlanması. Yüzüncüyl Üniversitesi, Fen Bilimleri Enstitüsü, Bahçe Bitkileri Anabilim Dal, Doktora Tezi [Phenological, morphological, pomological and molecular identification of apple genetic resources in Posof (Ardahan) region. Yüzüncüyll University, Graduate School of Natural and Applied Sciences, Department of Horticulture, $\mathrm{PhD}$ Thesis].

Robinson JP, Harris SA, Juniper BE (2001). Taxonomy of the genus Malus Mill. (Rosaceae) with emphasis on the cultivated apple, Malus domestica Borkh. Plant Systematics and Evolution 226(1-2):35-58.

Sadik CD, Sies H, Schewe T (2003). Inhibition of 15-lipoxygenases by flavonoids: structure activity relations and mode of action. Biochemical Pharmacology 65(5):773-781.

Savolainen V, Corbaz R, Moncousin C, Spichiger R, Manen JF (1995). Chloroplast DNA variation and parentage analysis in 55 apples. Theoretical and Applied Genetics 90(7-8):1138-1141.
Serdar B, Karaköse M, Mazlum R, Öztürk M, Çağdaş G Terzioğlu S (2014). Türkiye'de Doğal Olarak Yetişen Amelanchier Medik. Taksonlarının Odun Anatomileri [Amelanchier medicinal naturally grown in Turkey. Wood Anatomy of Taxa]. Biyoloji Bilimleri Araştırma Dergisi 2:30-33.

Sesli M, Yegenoglu ED (2017). Genetic relationships in wild olives (Olea europaea ssp. oleaster) by ISSR and RAPD markers. Biotechnology and Biotechnological Equipment 31(5): 897-904.

Swofford DL (2002). PAUP*. Phylogenetic Analysis Using Parsimony ("and Other Methods). Version 4b10-x86- macosx. Sinauer Associates, Sunderland, Massachusetts.

Uzun A, Ozongun S, Gulsen O, Yllmaz KU, Kaymak S, Ercisli S (2016). Determination of genetic relatedness among Turkish apple germplasm based on ISSR markers. Journal of Applied Botany and Food Quality 89:82-88.

Wiseman A (2001). Biologically-active phytochemicals in food: analysis, metabolism, bioavailability and function. Pfannhauser W, Fenwick GR, KhokharS(Eds). The Royal Society ofChemistry, Cambridge.

Wolfe KL, Liu RH (2003). Apple peels as a value-added food ingredient. Journal of Agricultural and Food Chemistry 51(6):1676-1683.

Wolfe KL, Wu X, Liu RH (2003). Antioxidant activity of apple peels. Journal of Agriculture and Food Chemistry 51(3):609-614.

Zarei A, Erfani-Moghadam J, Mozaffari M (2017). Phylogenetic analysis among some pome fruit trees of Rosaceae family using RAPD markers. Biotechnology and Biotechnological Equipment 31(2):289298.

Zietkiewicz E, Rafalski A, Labuda D (1994). Genome fingerprinting by simple sequence repeat (SSR)-anchored polymerase chain reaction amplification. Genomics 20(2):176-183. 